\title{
RESULTS OF THE USE OF PEEK CAGES IN THE TREATMENT OF BASILAR INVAGINATION BY GOEL TECHNIQUE
}

\author{
RESULTADOS DO USO DE CAGE EM PEEK NO TRATAMENTO DA INVAGINAÇÃO BASILAR \\ PELA TÉCNICA DE GOEL
}

\author{
RESULTADOS DE LA UTILIZACIÓN DE CAJA DE PEEK EN EL TRATAMIENTO \\ DE LA INVAGINACIÓN BASILAR POR LA TÉCNICA DE GOEL
}

Luís Eduardo Carelli Teixeira da Silva ${ }^{1}$, Alderico Girão Campos de Barros ${ }^{1}$, Calque Jauhar de Castro', Raphael Teofilo de Souza ${ }^{1}$, Gustavo Borges laurindo Azevedo', Priscila ladeira Casado ${ }^{1}$

1. Instituto Nacional de Traumatologia e Ortopedia, Rio de Janeiro,RJ, Brasil.

\begin{abstract}
Objective: Analysis of the use of polyetheretherketone (PEEK) cages for atlantoaxial facet realignment and distraction for treatment of basilar invagination by Goel technique. Method: Retrospective descriptive statistical analysis of the neurological status, pain, presence of subsidence and bone fusion with the use of PEEK cages in 8 atlantoaxial joints of 4 patients with basilar invagination. All patients were treated with atlantoaxial facet distraction and realignment and subsequent arthrodesis C1-C2 by the technique of Goel modified by the use of PEEK cage. Results: All patients showed improvement in Nurick neurological assessment scale and Visual Analogue Scale (VAS) of pain. There were no cases of subsidence, migration, or damage to the vertebral artery during the insertion of the cage. All joints evolved with bone fusion, assessed by dynamic radiographs, and computed tomography. Two patients developed neuropathic pain in dermatome of $\mathrm{C} 2$ and one patient had unilateral vertebral artery injury during $\mathrm{C} 2$ instrumentation treated with insertion of pedicle screw to control the bleeding. Conclusion: The results of the treatment of basilar invagination by the Goel technique with the use of PEEK cages shown to be effective and safe although further studies are needed to confirm this use.
\end{abstract}

Keywords: Platybasia; Skull base; Atlanto-axial joint.

\section{RESUMO}

Objetivo: Análise do uso do implante tipo cage em poli-éter-éter-cetona (PEEK) no realinhamento e distração facetária atlantoaxial da invaginação basilar pela técnica de Goel. Método: Análise estatística descritiva retrospectiva de estado neurológico, dor, presença de fusão óssea e subsidência com o uso do cage em PEEK em 8 articulações atlantoaxiais de 4 pacientes portadores de invaginação basilar, todos tratados com distração, realinhamento atlantoaxial e artrodese posterior C1-C2 pela técnica de Goel, modificada pela utilização do cage em PEEK. Resultados: Todos os pacientes apresentaram melhora na escala de avaliação neurológica de Nurick e na Escala Visual Analógica (EVA) de dor. Não ocorreu caso de subsidência, migração ou dano à artéria vertebral decorrente da colocação do cage. Cem por cento das articulações evoluíram com fusão óssea, avaliada por radiografia dinâmica e tomografia computadorizada. Dois pacientes evoluíram com dor neuropática no dermátomo de C2 e em um paciente houve lesão unilateral da artéria vertebral durante a instrumentação de C2, tratada com inserção do parafuso pedicular para controle do sangramento. Conclusão: Os resultados da redução vertical da invaginação basilar pela técnica de Goel com a utilização de cage em PEEK mostrou ser eficaz e segura, porém ainda são necessários estudos para confirmar essa utilização.

Descritores: Platibasia; Base do crânio; Articulação atlantoaxial.

\section{RESUMEN}

Objetivo: Análisis del uso del implante tipo caja en poli-éter-éter-cetona (PEEK) en el realineamiento y distracción facetaria atlantoaxial de la invaginación basilar por la técnica de Goel. Métodos: Fue realizado un análisis estadístico descriptivo retrospectivo del status neurológico, dolor, presencia de fusión ósea y hundimiento con el uso de la caja en PEEK en 8 articulaciones atlantoaxiales de 4 pacientes que presentaban invaginación basilar, todos tratados con distracción y realineamiento atlantoaxial y artrodesis posterior C1-C2 mediante la técnica de Goel. Resultados: Todos los pacientes presentaron mejoría en la escala de evaluación neurológica de Nurick y en la Escala Visual Analógica (EVA) del dolor. No hubo casos de hundimiento, migración o daño a la arteria vertebral debido a la colocación del implante. El 100\% de las articulaciones evolucionaron con fusión ósea evaluada por radiografía dinámica y tomografía computarizada. Dos pacientes evolucionaron con dolor neuropático en el dermatomo de C2, y en un paciente hubo lesión unilateral de la arteria vertebral durante la instrumentación de C2, tratada con inserción de un tornillo pedicular para control del sangrado. Conclusión: Los resultados de la reducción vertical de la invaginación basilar por la técnica de Goel con el uso de caja en PEEK han demostrado ser eficaz y segura pero se necesitan más estudios para confirmar este uso.

Descriptores: Platibasia; Base del cráneo; Articulación atlantoaxoidea.

Work carried out at the Instituto Nacional de Traumatologia e Ortopedia [National Institute of Traumatology and Orthopedics], Rio de Janeiro, RJ, Brazil.

Correspondence: Rua Araguaiana, 1266, Bloco 05, Ap 606 - Freguesia, Rio de Janeiro, RJ. 2745-271. luiscarelli@uol.com.br 


\section{INTRODUCTION}

Pathologies of the craniocervical junction represent a great challenge for spine surgeons, due to the anatomical singularity of the region, which contains extremely important neurovascular structures, as well as the complex visualization and interpretation of the osteoligamentary structures and biomechanical peculiarities of this segment of the cervical spine. Numerous pathologies can lead to degeneration of the craniocervical junction, such as congenital malformations, trauma, metabolic diseases, rheumatoid arthritis, and primary osteoarthritis, among others. Congenital basilar invagination is a rare abnormality in which the odontoid process is in a higher position than normal, projecting into the interior of the foramen magnum, which can cause neurological symptoms, limiting the space available for the brainstem and spinal cord. In patients with classic basilar invagination, classified by Goel as group $A$, there appears to be significant atlantoaxial instability, and the respective facets have an oblique arrangement, instead of their usual horizontal orientation. It is considered that the atlantoaxial joint is "active", leading to cranial migration and flexion of the odontoid process.

A wide range of surgical techniques has been described for decompression and stabilization of the craniocervical junction in patients with basilar invagination. Traditionally, the proposed treatment in symptomatic cases is transoral resection of the dens of the axis, with posterior stabilization through occipitocervical fusion. ${ }^{2}$ In recent years, the technique described by Goel et al. ${ }^{1}$ has gained increasing importance in the treatment of this pathology. This technique consists of indirect decompression of the foramen magnum by reducing the odontoid process through the opening of the joints of the lateral masses of $\mathrm{C} 1$ and $\mathrm{C} 2$, and stabilizing these through instrumentation with lateral mass screws in the atlas, and pedicle screws in the axis. The whole procedure is performed via posterior access, sparing the patient the known morbidity of direct transoral decompression and other extended superior approaches.. ${ }^{3.4}$ Distraction of the facet joints and decortication of their joint surfaces, besides promoting reduction of the atlantoaxial joint, provide an additional bed for the bone fusion. (Figure 1)

Originally, the technique of Goel used a stainless steel cage to maintain the craniovertebral realignment, together with autologous graft of the posterior iliac crest. ${ }^{1}$ In our cases, we used a polyetheretherketone (PEEK) cage, as we believe it has some theoretical advantages: lower subsidence rate, higher consolidation rate, and better visualization in imaging examinations during postoperative follow-up. The aim of this work is to carry out a retrospective clinical and radiological examination of the results of atlantoaxial facet distraction using PEEK cage in the treatment of basilar invagination.

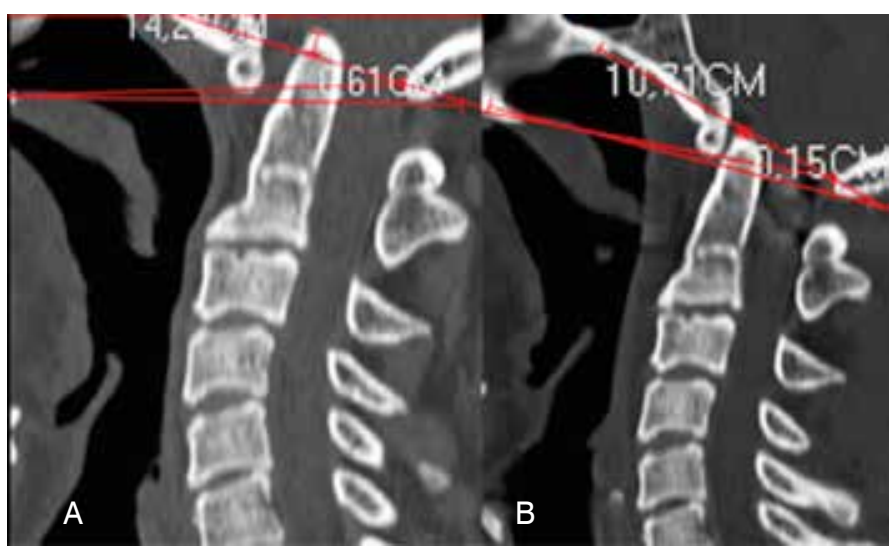

Figure 1. Sagittal section of computed tomography before (A) and after (b) indirect decompression by atlantoaxial facet distraction with PEEK cage. The lines of McGregor, Chamberlaim and McRae prove caudal migration and realignment of the odontoid process.

\section{MATERIALS AND METHODS}

This study is a retrospective analysis of 8 cages in four patients with Goel Group A basilar invagination. All the patients were submitted to indirect decompression by atlantoaxial facet distraction and posterior fusion, using the technique of Goel. ${ }^{1}$ As a technical modification, we used a PEEK cage as intraarticular C1-C2 spacer, and polyaxial screws and titanium rods for the monosegment fusion. All the patients were operated by the same surgical team during the years 2013 and 2014, and all signed the informed consent form. In all patients, the Visual Analog Scale (VAS) ${ }^{5}$ and the Nurick myelopathy scale ${ }^{6}$ were adopted as postoperative evaluation. These scales were also used in the postoperative follow-up.

As this is purely a review article of patient records and description of a new surgical technique, it did not require submission to the ethics committee.

Three patients were female and one was male. The mean age was $50.25 \pm 8.01$ years (39 to 58 years); the mean follow-up time of these patients was $16 \pm 6.48$ months ( 9 to 22 months). The patients were followed up on an outpatient basis, with evaluation at 3, 6 and 9 months after surgery through a neurological examination and control computed tomography at 6 months after surgery. Descriptive statistical analysis was carried out using the software STATA 11.1 (StataCorp, Texas, USA), considering the nominal and numerical variables.

\section{Surgical Technique}

The patient was positioned in ventral decubitus, with the head of the table elevated degrees after installation of cranial traction with $1 / 8$ of body weight. Longitudinal access was performed along the midline, with subperiosteal exposure of the craniocervical junction. The ganglion of $\mathrm{C} 2$ was identified and sectioned bilaterally to allow wide exposure of the atlantoaxial facet joints. In many cases of basilar invagination, it is common to find malformations, such as occipitalization of the atlas and more rostral localization of the facet of $\mathrm{C} 1$, which complicates the procedure. The atlantoaxial facet joint capsules are excised, and the joint surfaces are exposed. In order to reduce the invagination through facet distraction, progressively larger osteotomies are introduced and turned 90 degrees, to provide sufficient space for the introduction of the tests using PEEK cages of $5 \times 11 \times 14 \mathrm{~mm}$ or $5 \times 12.5 \times 14 \mathrm{~mm}$ used in conventional subaxial cervical fusion surgeries ${ }^{7}$ containing spongy bone taken from the patient's posterior iliac crest. (Figure 2). Instrumentation is performed with screws in the lateral mass of $\mathrm{C} 1$ and pedicle screws in C2, according to the technique of Goel-Harms. ${ }^{8.9}$ The surgical wound is closed by planes, without drainage, and the patient is advised to use a Philadelphia type collar for 12 weeks.

\section{RESULTS}

There was no case of infection of the surgical wound, worsening of the deficit, or death. All patients improved by at least one degree in the neurological evaluation by the Nurick scale. ${ }^{6}$ The evaluation of the position of the odontoid process before and

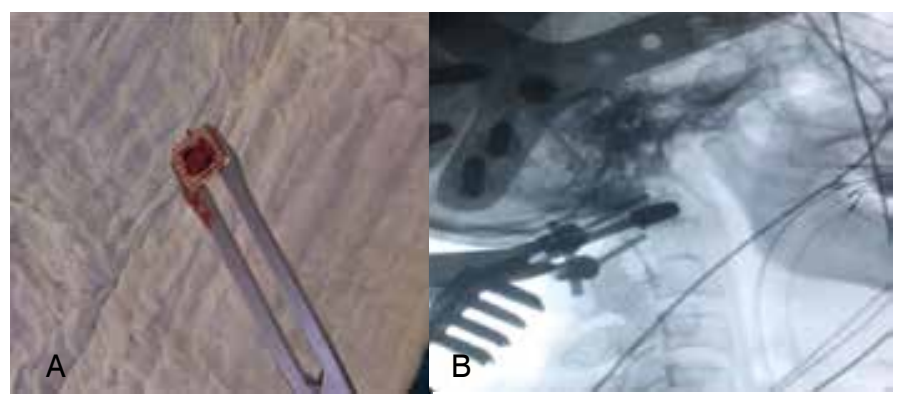

Figure 2. (a) Intraoperative image showing PEEK cage containing autologous bone graft from the iliac crest. (b) Intraoperative fluoroscopy showing the insertion of the cage test in the atlantoaxial interfacet space. 
after surgery showed satisfactory reduction. There was no case of subsidence, migration, or damage to the vertebral artery when placing the cage in all eight joints of four patients operated on. (Table 1) Dynamic radiographs of the craniocervical junction and computed tomography showed bone fusion in 100\% of the joints. The criteria for fusion that we used was the presence of a bone bridge in coronal and/or sagittal sections, and the absence of mobility in dynamic radiographs performed 6 months after surgery. (Figure 3) As a complication, two patients had intense neuropathic pain in the dermatome of $\mathrm{C} 2$, which persisted for 3 months in one case and 15 days in another. After this period, there was complete resolution of pain, with persistence only of local hypoesthesia. In one case, there was unilateral lesion of the vertebral artery during the instrumentation of $\mathrm{C} 2$, which was treated with insertion of a pedicle screw to control the bleeding. The patient awakened and remained for 3 months without neurological changes related to the lesion of the vertebral artery, and after this period, developed unilateral amaurosis ipsilateral to the lesion of the vertebral artery. However, magnetic angioresonance showed a pervious vertebrobasilar system, ruling out the lesion of the artery as a causal factor. The patient remains under etiological investigation.

Table 1. Clinical and radiological results.

\begin{tabular}{c|c|c|c|c|c|c|c}
\hline Patient & $\begin{array}{c}\text { VAS } \\
\text { Pre/ } \\
\text { post (6 } \\
\text { m) }\end{array}$ & $\begin{array}{c}\text { Pre/ } \\
\text { Post } \\
\text { Nurick }\end{array}$ & $\begin{array}{c}\text { Consoli- } \\
\text { dation } \\
\text { Right/ } \\
\text { Left }\end{array}$ & $\begin{array}{c}\text { Subsi- } \\
\text { dence } \\
\text { Right/ } \\
\text { Left }\end{array}$ & $\begin{array}{c}\text { Macrae } \\
\text { Pre/Post }\end{array}$ & $\begin{array}{c}\text { McGre- } \\
\text { gor } \\
\text { Pre/Post }\end{array}$ & $\begin{array}{c}\text { Chamber- } \\
\text { lain } \\
\text { Pre/Post }\end{array}$ \\
\hline 1 & $8 / 1$ & $I / 0$ & $+/+$ & $\phi / \phi$ & $0.18 / 0.35$ & $1,1 / 0,91$ & $0.89 / 0.7$ \\
\hline 2 & $4 / 1$ & $\mathrm{IV} / \mathrm{I}$ & $+/+$ & $\phi / \phi$ & $-0.61 / 0.15$ & $1,98 / 0,93$ & $1.58 / 0.7$ \\
\hline 3 & $6 / 2$ & $\mathrm{III/I}$ & $+/+$ & $\phi / \phi$ & $0.21 / 0.4$ & $0,92 / 0,72$ & $0.69 / 0.49$ \\
\hline 4 & $4 / 1$ & $\mathrm{IV} / \mathrm{II}$ & $+/+$ & $\phi / \phi$ & $0.15 / 0.33$ & $1,26 / 1,03$ & $1.01 / 0.76$ \\
\hline
\end{tabular}

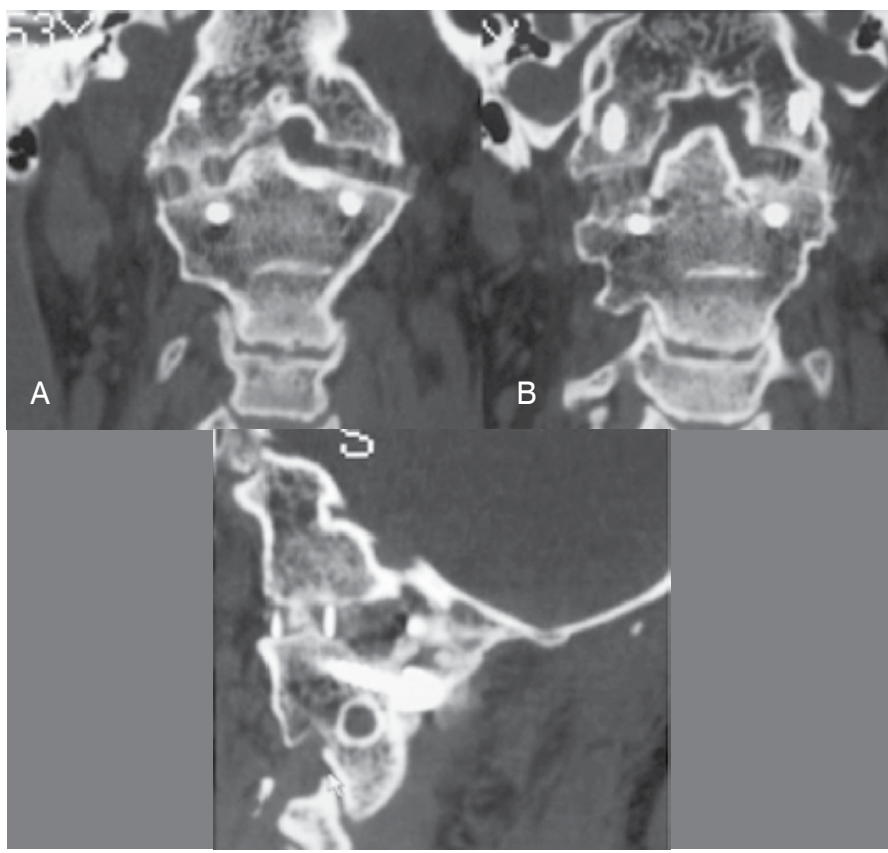

Figure 3. Computed tomography 6 months after surgery confirms consolidation with the presence of a bilateral bone bridge and adequate positioning of the PEEK cage in the atlantoaxial interfacet space. Coronal section (A) and (B), sagittal section $(\mathrm{C})$.

\section{DISCUSSION}

The projection of the odontoid process into the foramen magnum above the lines of McRae ${ }^{10}$, according to Chamberlain ${ }^{11}$ confirms the presence of basilar invagination. In the presence of symptoms, the treatment traditionally proposed is transoral resection of the odontoid process, associated with posterior occiptocervical fusion. However, this procedure has well-established risks, the most feared one being the occurrence infection following transoral decompression, ${ }^{3}$ added to the high morbidity of occiptocervical fusion, which promotes a significant loss of flexion-extension and lateral rotation of the head and neck. ${ }^{12,13}$ Successful occipitocervical fusion has been reported by some authors. ${ }^{14}$ However, the majority of studies show poor results when associated transoral decompression is not performed, with the reappearance of symptoms after a while, due to the loss of gain in distraction during surgery. ${ }^{1.2}$ The use of shorter constructions with smaller rods and longer bolts in $\mathrm{C} 1$ and $\mathrm{C} 2$ provides biomechanical advantages in relation to longer instrumentations and smaller screws involving the occiput, which is much thinner. ${ }^{8}$

In recent years, the classification of basilar invagination in Group A or Group B, and the technique of atlantoaxial facet realignment and distraction proposal by Goel et al. ${ }^{1}$ has gained increasing numbers of followers. The technique spares the patient the morbidity associated with the transoral approach, and performing a monosegment fusion by the posterior approach minimizes the loss of range of movement of the cervical spine, while at the same time, provides sufficient biomechanical stability to the craniocervical junction. ${ }^{15,16}$ Alongside the advantages already mentioned, exposure of the facet joints of $\mathrm{C} 1$ and $\mathrm{C} 3$ promotes additional bone bed for the consolidation of the fusion, and maintenance of indirect decompression and reduction of the odontoid process. The original description of this technique uses stainless steel cages, but we believe in the theoretical advantages of PEEK cage, therefore we decided to use it.

Although the scientific literature on the use of the PEEK cage in the craniocervical junction is scarce, ${ }^{15,16}$ by analogy with its use in conventional anterior arthrodesis of the subaxial cervical spine, we can believe in some potential advantages of this material in surgery of the craniocervical joint, which is what prompted us to use the PEEK cage. In the initial cases performed by the technique of Goel, a Harms basket type cage was used. However, one patient in this first series, after a year of improvement in neurological symptoms, evolved with reappearance of the symptoms. The patient's computed tomography showed significant subsidence, and the patient was submitted to review by transoral decompression. ${ }^{17}$ In anterior intersomatic cervical fusion surgeries, PEEK cages presented some advantages over metal cages. It is known that onset of subsidence is related to the preparation of the terminal plates, the size of the contact surface of the implant, the amount of distraction applied during surgery, and the quality of the patient's bone. ${ }^{18,19}$ However, the most important variable related to the presence of subsidence is the material from which the cage is manufactured. ${ }^{20}$ The elasticity module of the PEEK cage is similar to that of bone, a characteristic that is attributed to the lower rate of subsidence than metallic cages, and the lower likelihood of stress shielding. A frame cage design enables a large amount of bone graft to be installed in its interior, and is another factor that can assist in bone fusion, ${ }^{21}$ facts that were observed in our cases. Another special feature of cage in PEEK is the higher radioluminescence of the material and the generation of less artifact, which facilitates the confirmation of bone consolidation in plain radiographs and control computed tomography scans during the follow-up of patients. ${ }^{21}$ Unlike the stainless steel cage initially used by Goel ${ }^{22}$, the PEEK cage is compatible with the performance of postoperative magnetic resonance imaging, which enables the evaluation of syringomyelia, Chiari malformation, and changes in spinal cord signal, abnormalities commonly associated with basilar invagination. This is another potential advantage of the use of a PEEK cage over metallic cages. (Figure 4). 


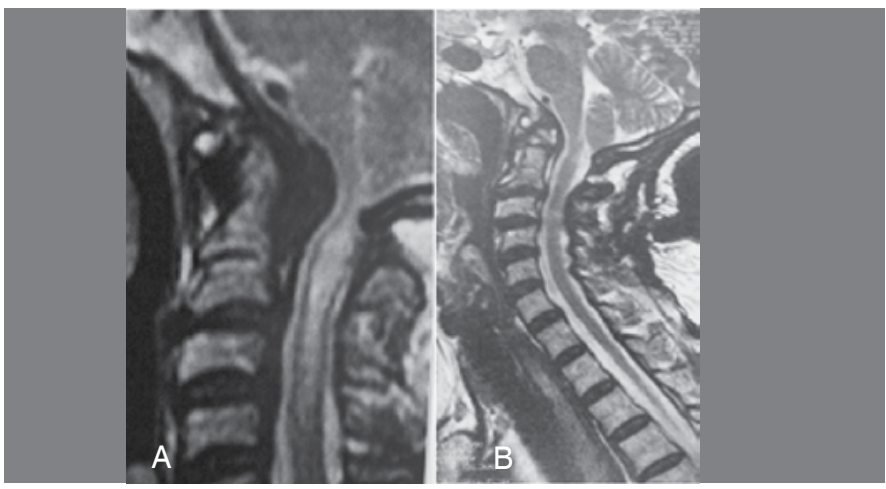

Figure 4. Preoperative sagittal T2-weighted MRI scan showing basilar invagination, retro-odontoid pseudotumor, and syringomyelia (A). Postoperative sagittal T2-weighted MRI scan performed 3 months after surgery showing a reduction in basilar invagination, syringomyelia and buckling (B).
The occurrence of neuropathic pain in $50 \%$ of our patients, which we attributed to the resection of the $\mathrm{C} 2$ ganglion for visualization and exposure of the atlantoaxial joints, was a relevant clinical complication, and does not coincide with the proportion of this complication in other, larger series described in literature. ${ }^{16,23}$ On the other hand, our small series does not allow us to establish the real incidence of this complication.

\section{CONCLUSION}

Vertical reduction of the basilar invagination by the Goel technique with the use of a PEEK cage proved to be safe and effective, allowing adequate postoperative follow up with imaging exams. Long-term multicenter studies are needed to confirm this.

All authors declare no potential conflict of interest concerning this article.

AUTHOR CONTRIBUTIONS: Each author made a significant contribution to the development of the scientific work. LECTS was the supervisor and pioneer of the work. LECTS and AGCB were the main surgeons and conducted the bibliographic review and outline of the work. RTS conducted the bibliographic review, writing of the text, analysis of the patient data, and translation of the abstract into Spanish. CJC and GBLA were responsible for analysing the radiological images in Surgimap and translating the text into English. RTS and GBLA revised the text. PLC performed the statistical analysis of the data.

\section{REFERENCES}

1. Goel A. Treatment of basilar invagination by atlantoaxial joint distraction and direct lateral mass fixation. J Neurosurg Spine. 2004;1(3):281-6.

2. Goel $A$, Bhatjiwale M, Desai K. Basilar invagination: a study based on 190 surgically treated patients. J Neurosurg. 1998:88(6):962-8.

3. Jones DC, Hayter JP. The superiorly based pharyngeal flap: a modification of the transoral approach to the upper cervical spine. Br J Oral Maxillofac Surg. 1997;35(5):368-9.

4. Carneiro Filho GS. Acesso cirúrgico anterior no tratamento da invaginação basilar. In: Silva JAG. Malformações occipitocervicais. Recife, PE: Ed. Universitária da UFPE; 2003. p. 445-59.

5. Huskisson EC. Measurement of pain. J Rheumatol. 1982;9(5):768-9.

6 . Nurick S. The pathogenesis of the spinal cord disorder associated with cervical spondylosis. Brain. 1972:95(1):87-100.

7. Texeira da Silva LEC, Azevedo GBL, Chaves BJM. Fixed Atlantoaxial dislocation with cord compression: treatment with c1-c2 joint jamming: a case presentation. In: Gupta MC, Vaccaro RA, Gupta S, editors. Complex spine cases: a collection of current techniques. London: Jaypee; 2015. p. 238-44.

8. Goel A, Laheri V. Plate and screw fixation for atlanto-axial subluxation. Acta Neurochir (Wien). 1994;129(1-2):47-53.

9. Harms J, Melcher RP. Posterior C1-C2 fusion with polyaxial screw and rod fixation. Spine (Phila Pa 1976). 2001;26(22):2467-71.

10. MCRAE DL. Bony abnormalities in the region of the foramen magnum: correlation of the anatomic and neurologic findings. Acta radiol. 1953:40(2-3):335-54.

11. Chamberlain WE. Basilar Impression (Platybasia): A bizarre developmental anomaly of the occipital bone and upper cervical spine with striking and misleading neurologic manifestations. Yale J Biol Med. 1939;11(5):487-96.

12. Henriques T, Cunningham BW, Olerud C, Shimamoto N, Lee GA, Larsson S, et al. Biomechanical comparison of five different atlantoaxial posterior fixation techniques. Spine (Phila Pa 1976). 2000;25(22):2877-83
13. Magerl F Seemann P-S. Stable posterior fusion of the atlas and axis by transarticular screw fixation. In: Kehr P, Weidner A, editors. Cervical spine I. New York: Springer; 1986. p. 322-7. 14. Jian FZ, Chen Z, Wrede KH, Samii M, Ling F. Direct posterior reduction and fixation for the treatment of basilar invagination with atlantoaxial dislocation. Neurosurgery. 2010;66(4):678-87

15. Park J, Scheer JK, Lim TJ, Deviren V, Ames CP. Biomechanical analysis of Goel technique for C1-2 fusion. J Neurosurg Spine. 2011;14(5):639-46.

16. Hong JT. Reduction Techniques for the treatment of upper cervical deformity. Em www. vumedi.com

17. Silva LEC, Azevedo GBL, Chaves BM, Tavares RH, Barros AGC, Schettino, LCV. Resultados da manipulação e distração facetária atlantoaxial para o tratamento das instabildades crânio-vertebrais. Coluna/Columna. 2013:12(3 Edição Especial):274. Disponível em: http:// www.plataformainterativa2.com/coluna/html/revistacoluna/volume12/coluna_v12n3_ anais_congresso_cbc_2013_p253-275.pdf

18. Barsa P, Suchomel P. Factors affecting sagittal malalignment due to cage subsidence in standalone cage assisted anterior cervical fusion. Eur Spine J. 2007:16(9):1395-400.

19. Truumees E, Demetropoulos CK, Yang KH, Herkowitz HN. Effects of disc height and distractive forces on graft compression in an anterior cervical discectomy model. Spine (Phila Pa 1976). 2002:27(22):2441-5.

20. Katzer A, Marquardt $H$, Westendorf J, Wening JV, von Foerster G. Polyetheretherketone-cytotoxicity and mutagenicity in vitro. Biomaterials. 2002;23(8):1749-59.

21. Niu CC, Liao JC, Chen WJ, Chen LH. Outcomes of interbody fusion cages used in 1 and 2-levels anterior cervical discectomy and fusion: titanium cages versus polyetheretherketone (PEEK) cages. J Spinal Disord Tech. 2010;23(5):310-6.

22. Goel A. Is atlantoaxial instability the cause of Chiari malformation? Outcome analysis of 65 patients treated by atlantoaxial fixation. J Neurosurg Spine. 2015;22(2):116-27.

23. Goel A, Desai KI, Muzumdar DP. Atlantoaxial fixation using plate and screw method: a report of 160 treated patients. Neurosurgery. 2002;51(6):1351-6. 